\title{
Takaful Diat: Alternative Compensation Mechanism for Road Accidents in Malaysia
}

\author{
Lukman AM, Ahmad Syukran, Wan Abdul Fattah
}

\begin{abstract}
This paper seeks to assess the suitability of "Takaful Diat" taking over the definition of 'aqilah (the group of people who share the blood-money liability of any one among them), and subsequently, becoming the feasible alternative in dealing with the complicated issue of road accidents compensation in Malaysia. The paper opted for a qualitative study where the authors discussed the concept of Diat (blood-money) and Takaful (Islamic insurance) from the opinions of the Muslim scholars from the various schools of thoughts. Based on the current situation, it can be argued that takaful insurance companies are more than capable of being the 'aqilah so much so that the paper is convinced that they are the ones who capable of shouldering the responsibility. As such, the government needs to study a mechanism that could make such a contribution compulsory for every individual. Through Takaful Diat, the victims' welfare will be safeguarded. Takaful Diat provides protection through a specially designed insurance scheme that pays a victim with a specific amount of compensation which is determined by Syarak.
\end{abstract}

Index Terms: Takaful, takaful diat, Islamic insurance, road accidents, compensation, tort, diat, aqilah

\section{INTRODUCTION}

Takaful Diat is suggested as an alternative to accidents compensation in Malaysia. Etymologically, Takaful Diat is the end-result of two combined concepts i.e. takaful concept and Diat concept. In general, Takaful Diat serves as a social obligation mechanism in managing financial compensation for victims especially in cases involving road accidents. Takaful, on one hand, means cooperating and helping each other. Takaful concept is almost similar to that of insurance concept in which the fortunate will help out the unfortunate. It also suits a Quranic verse which means; “....and cooperate in righteousness and piety..." (Surah Al-Maidah: 5). Diat, on the other, means a compensation mechanism for the victims. The amount of Diat is determined by the rules of Shariah based on Quran and Hadith.

Through Takaful Diat, the victims' welfare will be safeguarded. The protection is provided through a specially designed insurance scheme that pays a victim with a specific amount of compensation. It is special in the sense that it is implemented with utmost professionalism devoid of selfish interests. The amount of compensation under Takaful Diat is determined by the law of Shariah. The nexus of the paper is to discuss the implementation mechanism of the system in Malaysia. It is sincerely hoped that it will provide an impetus for a deeper and extensive intellectual discourse of the matter in the future. The paper discussed the suitability of Takaful

Revised Version Manuscript Received on September 16, 2019.

Lukman Abdul Mutalib, Faculty of Sharia and Law, Universiti Sains Islam Malaysia, Bandar Baru Nilai, Negeri Sembilan, Malaysia.

Ahmad Syukran Baharuddin, Faculty of Sharia and Law, Universiti Sains Islam Malaysia, Bandar Baru Nilai, Negeri Sembilan, Malaysia.

Wan Abdul Fattah Wan Ismail, Faculty of Sharia and Law, Universiti Sains Islam Malaysia, Bandar Baru Nilai, Negeri Sembilan, Malaysia.
Diat in taking over the definition of 'aqilah and promotes the implementation of Takaful Diat as an alternative to the existing compensation mechanism for road accidents in Malaysia. The current paper explores on the significance of having a fair compensation system

\section{THE OBLIGATION FOR A FAIR COMPENSATION SYSTEM}

The issue of Diat is a modern-day problem. Since it cannot be detached from the human's daily activity, each and every member of the society should have a clear understanding of the concept of Diat. Taking into account the surging numbers of road accidents over the years, with no signs of them lessening rapidly in the near future, the need to understand the concept has become even more critical. Fatal and non-fatal road accidents are a national problem for Malaysia. No longer they are exclusive to festival or holiday breaks, they are now a daily incident that makes the news headlines every day. A study shows many factors for them. The lists are long but chief among them are unsafe vehicle condition, bad maintenance of roads, the weather, sudden and unavoidable accidents and at the top of the list, road users attitude [21].

Looking at the road accidents statistic issued by PDRM (Table 1), it shows an extremely high ratio of road accidents even only within a year. Despite the decreased numbers of accidents, the numbers of death and injury remain high within the first six months. Putting it differently, road accidents are responsible for the deaths of 21.06 for every 100,000 Malaysians (refer to Fig. 1). Road accident is currently the major killer of Malaysians. 
Takaful Diat: Alternative Compensation Mechanism for Road Accidents in Malaysia

Table 1: Road accidents statistic and indicator year 2011- September 2018

\begin{tabular}{|c|c|c|c|c|c|c|c|c|c|}
\hline \multicolumn{2}{|l|}{ Year } & 2011 & 2012 & 2013 & 2014 & 2015 & 2016 & 2017 & $\begin{array}{l}2018 \\
\text { (Sept) }\end{array}$ \\
\hline \multirow{3}{*}{$\begin{array}{l}\text { Types } \\
\text { of } \\
\text { Accident }\end{array}$} & $\begin{array}{l}\text { Death } \\
\text { Accident }\end{array}$ & 6,349 & 6,381 & 6,308 & 6,187 & 6,193 & 6,570 & 6,265 & 4,503 \\
\hline & $\begin{array}{l}\text { Major } \\
\text { Accident }\end{array}$ & 4,875 & 4,649 & 3,567 & 3,477 & 3,210 & 3,478 & 2,468 & 1,661 \\
\hline & $\begin{array}{l}\text { Minor } \\
\text { Accident }\end{array}$ & 9,438 & 9,398 & 6,523 & 7,099 & 5,733 & 5,527 & 4,919 & 3,267 \\
\hline \multicolumn{2}{|c|}{ Total No. of Accidents } & 20,662 & 20,428 & 16,398 & 16,763 & 15,136 & 15,575 & 13,652 & 9,431 \\
\hline \multicolumn{2}{|c|}{$\begin{array}{l}\text { Total No. of Accident Without } \\
\text { Injury (Damage Only) }\end{array}$} & 428,000 & 441,000 & 460,000 & 459,000 & 474,000 & 505,000 & 520,000 & 401,000 \\
\hline \multirow{3}{*}{$\begin{array}{l}\text { Types } \\
\text { of } \\
\text { Injury } \\
\end{array}$} & Death & 6,877 & 6,917 & 6,915 & 6,674 & 6,706 & 7,152 & 6,740 & 4,823 \\
\hline & Major Injury & 6,328 & 5,868 & 4,597 & 4,432 & 4,120 & 4,506 & 3,310 & 4,181 \\
\hline & Minor Injury & 12,365 & 11,654 & 8,388 & 8,598 & 7,432 & 7,415 & 6,539 & 2,250 \\
\hline \multicolumn{2}{|c|}{ Total No. of Injury } & 25,570 & 24,439 & 19,900 & 19,704 & 18,258 & 19,073 & 16,589 & 11,254 \\
\hline \multirow{3}{*}{$\begin{array}{l}\text { Fatal } \\
\text { Road } \\
\text { Accident } \\
\text { Index }\end{array}$} & $\begin{array}{l}\text { Index Per } \\
100,000 \\
\text { Population }\end{array}$ & 23.74 & 23.57 & 23.10 & 22.0 & 21.50 & 22.56 & 21.06 & NA \\
\hline & $\begin{array}{l}\text { Index Per } \\
10,000 \\
\text { Registered } \\
\text { Vehicles } \\
\end{array}$ & 3.21 & 3.05 & 2.90 & 2.66 & 2.55 & 2.59 & 2.34 & NA \\
\hline & $\begin{array}{l}\text { Index } \quad \text { Per } \\
\text { Billion VKT }\end{array}$ & 14.68 & 13.35 & 12.19 & 10.64 & 9.6 & 10.7 & 9.6 & NA \\
\hline
\end{tabular}

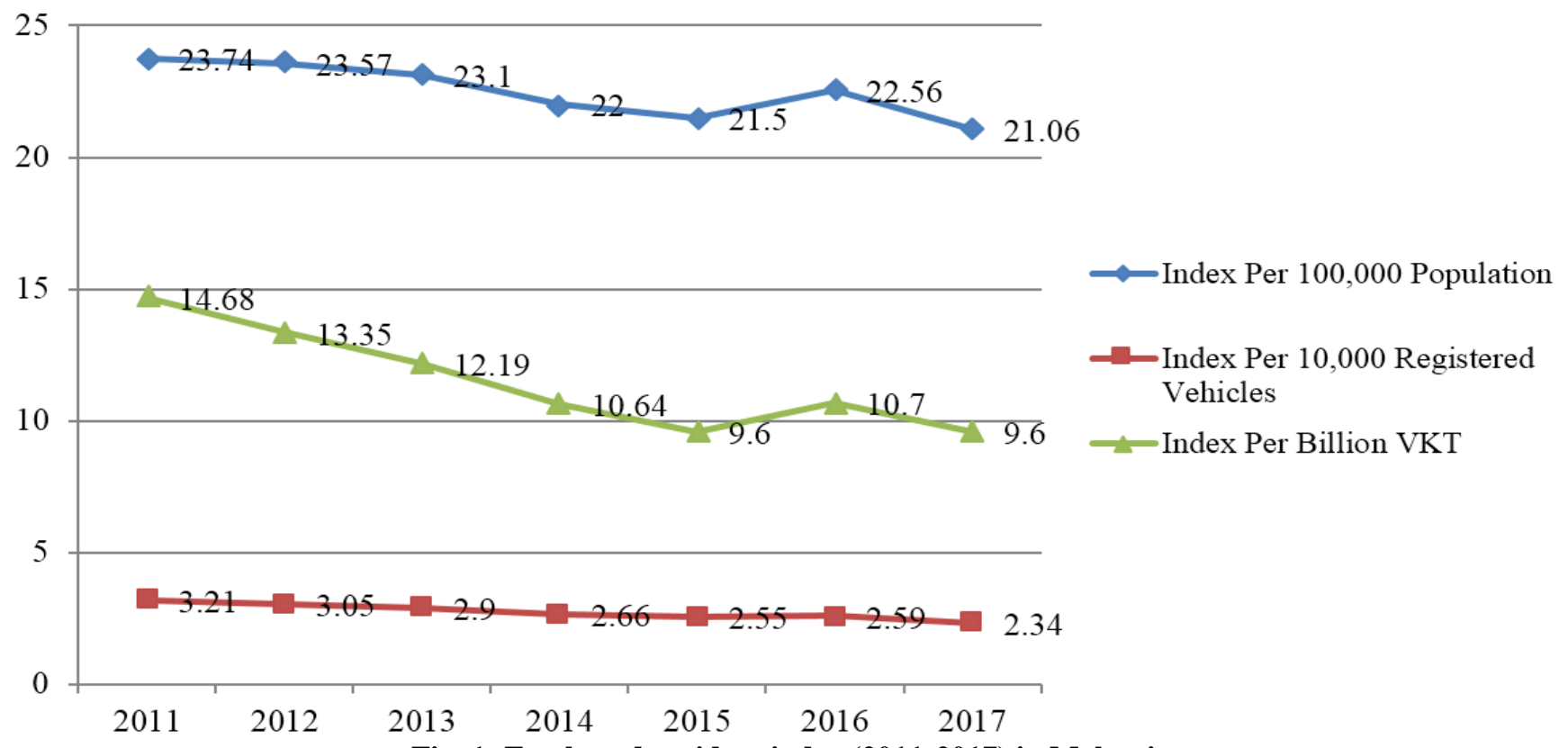

Fig. 1: Fatal road accident index (2011-2017) in Malaysia

Furthermore, the categories of road users involved in accidents, as per the record of Ops Statik IV which was carried out for 25 days i.e. 23 Dec 1999 - 17 Jan 2000. Within the period, 341 died, 1,960 were injured and 16,494 cases of road accidents were reported nationwide. It shows that $6.7 \%$ of the road users were involved in road accidents, while on their way back home or to their hometowns. The remaining 93.3\% were local road users going about their daily chores including the pedestrians [21]. Table 2 shows the statistic of accidents involving pedestrians for the year 2018 
International Journal of Recent Technology and Engineering (IJRTE)

ISSN: 2277-3878, Volume-8, Issue-2S11, September 2019

Table 2: Death statistic according to road users for the year 2018 (PDRM)

\begin{tabular}{|l|l|l|l|l|l|l|l|l|l|l|}
\hline \multicolumn{1}{|l|}{ Total No. of Road Users Death } \\
\hline Types of Vehicles /Month & Jan & Feb & March & April & May & June & Jul & Aug & Sept & Total \\
\hline Motorcycle & 327 & 323 & 396 & 379 & 384 & 371 & 342 & 357 & 300 & 3,179 \\
\hline Motorcar & 95 & 79 & 78 & 94 & 106 & 135 & 86 & 110 & 98 & 881 \\
\hline Pedestrian & 29 & 29 & 42 & 40 & 30 & 36 & 49 & 29 & 31 & 315 \\
\hline Lorry & 24 & 9 & 20 & 17 & 15 & 12 & 13 & 18 & 11 & 139 \\
\hline 4WD & 9 & 11 & 5 & 7 & 12 & 12 & 2 & 11 & 6 & 75 \\
\hline Others & 4 & 11 & 9 & 4 & 5 & 21 & 12 & 11 & 7 & 84 \\
\hline Bicycle & 18 & 9 & 13 & 6 & 7 & 9 & 13 & 12 & 7 & 94 \\
\hline Van & 7 & 4 & 4 & 1 & 2 & 3 & 5 & 3 & 4 & 33 \\
\hline Bus & 3 & 1 & 0 & 4 & 0 & 8 & 0 & 2 & 5 & 23 \\
\hline Total & 516 & 476 & 567 & 552 & 561 & 607 & 522 & 553 & 469 & 4,823 \\
\hline
\end{tabular}

All of the incidents above make the study even more topical and current. It has a two-pronged objective, firstly, it aims to underline the importance of fair compensation to the victims of road accidents. Secondly, it strives to play an effective role in reducing the occurrence of road accidents via the discussion of Diat system that follows. In fact, great numbers of Malaysian drivers do not possess insurance coverage.

Most of the time, in the event of a road accident, caused either by negligence or a third party's acts, victims tend to suffer the most severe consequences. Unfortunately, they are almost always left out on a fair redress or compensation. It is common to see the victims having to bear everything alone. This is obviously burdensome and is statistically proven by the cases of road accidents referred to. Not only do the victims have to endure a painful injury or even outright death, but they also stand to lose in the thousands of dollars for medical treatment and others. It becomes aggravated when the victims could not any longer work i.e. become physically and/or mentally disabled or impaired and therefore cease from being able to provide for their family or dependence.

In this context, victims would typically find themselves caught up and stuck in a seemingly abusive and repressive situation. However, things will be entirely different if the concept of Diat is put into effect. The fate of the victims is assured through the compensation monies the guilty party is legally obliged to pay. At the same time, this should also help in keeping the homeless, beggars and drifters off the streets.

But not all is lost for the guilty party. The system of Diat also covers for their rights because the payment of Diat is co-paid by 'aqilah. Indirectly, the responsibility to prevent crimes or road accidents due to negligence is now shared by both the convicted and the society, specifically, by their family members. This is hardly something new. Rather, in an interview with Utusan Malaysia Online on 27th October 2000, the former Inspector-General of Police, Tan Sri Norian Mai had highlighted the issue of mental patients going berserk (amuk). Tan Sri Norian argued that the responsibility to take preventive measures against such an ill-fated incidence, first and foremost, sat with the patients' family.

The concept is similar to that of Diat. The family, as well as the social institutions, must be equally responsible and take up a supporting role. Diat concept is therefore capable of nurturing the society's positive attitude towards crimes and road accidents caused by negligence. Each and every individual will share a common responsibility to deal with a communal issue or problem. Eventually, it will help the society to come up with an effective course of actions in order to deal with common concerns. Road accidents, especially those during festival holidays, do not only result in a huge loss for the family of the victims, it is also a massive national human capital loss. Every life lost to road accidents is a big loss to the country in the sense the country ceases to get a return for the high expenses it has spent on education and job training for the entire life of the victims.

\section{THE CONCEPT OF DIAT}

The word Diat means the property used as a medium of exchange for a life lost or a bodily injury caused [16]. Basically, the word of Diat comes from the Arabic root word of وَدَي (wadā) which means the rights of the killed. The use of the word Diat (دوديّ (دية) itself originates from the word (wadyūn). The letter ' $و$ ' before the word is changed to ' 0 ' before it is moved to the end of the word and thus turning (wadyūn) into دِيَّة (diat). Another similar example is when وَشْيْ (wašyūn) becomes شِيَّة (šiat). In a hadith, Prophet

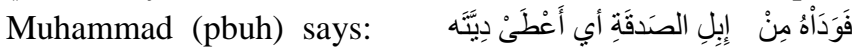
meaning: "So the Prophet pays him (a Jew) a Diat of camel" [18]. Literally, in [10] defines Diat as "the property that must be given to the victims of a murder crime or that which causes a bodily injury onto a free man". In addition, there are three parties who are directly involved in Diat: Diat payor, Diat payee and Diat payment. This paper seeks to discuss only the first party.

From the perspective of Fiqh in Islam, 'aqilah is considered to be the Diat payor in the event of an unintentional accident. Literally, 'aqilah comes from the word ع ('aql) which means to prevent or to restrain. A man of a sound mind عاقل ('âqil) is one who is capable of preventing or inhibiting oneself from free-falling into the unrestrained, wild indulgence of lusts. Besides, it is called "al-'aql" because it thwarts its master from being self-destructive [18]. At times, "al-'aql" can also be taken to have meant as Diat. Diat is

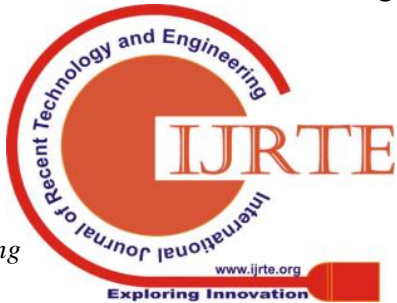


taken to be "al-'aql" because it prevents bloodshed from taking place. In addition to that, those having to bear the cost of Diat are referred to as 'aqilah.

Who is this 'aqilah? Scholars have conflicting views over this. According to the school of Hanafi, 'aqilah is 'Ahli Diwan' (أهل ديوان ) (al-Marghīnānī). 'Diwan’ is a department or agency in a state's administrative structure. 'Diwan' was first introduced during the administration of Saidina Umar al-Khattab. 'Ahli Diwan' refers to the soldiers who got themselves enlisted into 'Diwan' and were paid a salary for it. These soldiers must be of man gender, a free man, with a sound mind and of puberty age [5]. The equivalent of today's 'Diwan' is a ministry. If a person does not belong to a 'Diwan', his or her clan will be the 'aqilah.

For the School of Maliki, there are two categories of 'aqilah. Firstly, a tribe or a clan and secondly, the member of a 'Diwan'. Both of these 'aqilah must be of the same place. If anyone of them is in a different place, for example, one is Syria while the other is in Iraq, then both cannot be the 'aqilah for each other. There are two justifications for this. First, the School of Maliki considers the form of a Diat property must be referred to and in agreement with the local property instrument. As an instance, if a Syrian pays Diat using gold, he/she cannot ask an Iraqi to join him/her in paying off the Diat in gold because, in Iraq, Diat is paid using camel. Second, this highlights the fact that one of the requirements to be an 'aqilah is the presence of a likely fellow-feeling (of a kinship) to be able to help each other [15], [17].

For both of these Schools, 'aqilah refers to the 'asabah' relatives i.e. those who are entitled to inheritance the 'asabah' way [7], [11]. However, in this matter, both schools differ over the status of a father and a child.

i) The School of Imam Ahmad has two opinions. First: The father and the child are considered as 'aqilah.

Second: The father and the child cannot be considered as 'aqilah. This is also the stance of the School of Imam Syafi'e.

Upon considering the opinions of all four Schools, an important conclusion can be drawn, that is, the scholars' apprehension and understanding of who constitutes 'aqilah are based on the process of ijtihad and not tauqifi. Tauqifi refers to a matter prefixed by Allah (swt) via clear nas and comes with a central character of ta'abbud - more so since Diwan only came into being in the post-Prophet (pbuh) era. In the times of the Prophet (pbuh), 'aqilah was understood to have referred to all those under a family tree. In other words, when a member of the family received a punishment of Diat, the entire family members were obliged to help him or her paying off the Diat. However, this was no longer the case after the demise of the Prophet when Saidina Umar (ra) made 'Diwan' as 'aqilah. Although this was unprecedented, none of the companions objected to it and with the absence of such an objection, what Saidina Umar did was considered to be the right thing to do. If it was seen as having violated the Prophet's command, the companions would have not stayed in silence. The truth, Saidina Ali (ra) did not agree with
Saidina Umar (ra) over this issue. Despite him not objecting it. Tolerance among the companions in this matter was proof that it was a subject of 'ijtihadi'.

This is also a proof that the companions accepted that 'aqilah did not belong to the category of 'tauqifi'. On the contrary, it was considered to be a ruling issue related to illah'. 'Illah, in the sense of 'aqilah as an obligation is meant to provide for means to offer assistance or help النصرة (al-nusrah). During the time of the Prophet (pbuh), 'aqilah applied only to the next of kin while in the times of Saidina Umar, 'aqilah applied to the members of 'Diwan' i.e. members of Diwan were 'aqilah.

As such, conceptually, 'aqilah refers to a group of men and women who swear loyalty to help each other out both in the good and bad times. They band together as a group/tribe to shoulder a common responsibility. In summing up the preceding discussion, the following conclusions are in order:

i. 'Aqilah is based on 'ijtihad'. One of the reasons is the absence of a specific 'dalil' that provides a full meaning of 'aqilah. Besides, the companions were having differences of opinions as well on this matter. Moreover, the position of 'aqilah as one of the branches of 'muamalat' related to human everyday affairs allows for the intervention of 'ijtihad' when a 'maslahat' arises. With the consensual agreement that 'aqilah is a matter of ijtihadi, a difference in opinion is therefore common and normal. Seen from a positive perspective, not only it is congruent with human nature, it also blesses and liberates matters of the 'fiqh' in Islam. Saidina Umar (ra) b. Abd al-Aziz states [12]

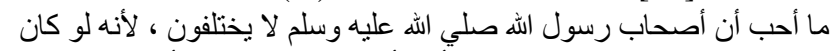

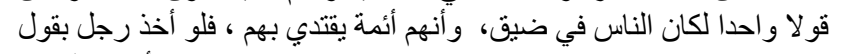
أحدهم لكان سنة

"I detest the idea suggesting that the companions of the Prophet have never differed in their opinions because should they have done otherwise, human's life would be hard done by. The companions are the 'imam' serving as the guide of the general public. Even if one were to take up the opinion of only one of the companions, it remains a 'sunnah'.

On a whole, when it comes to 'aqilah, scholar's opinions can be grouped into two major arguments:

a.

First, those who argue that 'aqilah refers to those considered as the next of kin either by the process of 'nasab' or wala'. The basis for this ruling is the mere kinship. Kinship here means those who have the rights of inheritance between and among each other. It suits a method of fiqh known as الغرم بالغنم (al-garami bil-ganami) which states that one's loss compensates one's gain [9]. This is the stand of Mazhab Syafi'e, Hambali, Zahiri and Shi'ites. b.

Second, those who argue that 'aqilah refers to those tied to each other in a strong and solid bond of social contract regardless of whether or not the contract is based on kinship or otherwise. Due to this contract, they are bound to help each other. The basis of this ruling lies in the 'illah for help and assistance التناصر (al-tanașur). If there is 'illah in a given social group, then it is to be taken as the 'aqilah. This argument is supported by Saidina Umar (ra) as well as the Schools of Hanafi and Maliki. 
Most importantly, these differences in opinions have given the Muslim Ummah the liberty of choosing the best based on the factors of time, place, urf (custom) and individual interests. This also does Islam a great favor because it credits Islamic law with flexibility and universality across all ages in all places.

\section{THE CONCEPT OF TAKAFUL}

In the preceding pages, the paper has discussed the multiple interpretations of the term 'ahli Diwan': as long as the entity is in possession of 'illat al-tanasur' for and to each other, it can be taken to mean any agency of either the government or the private sectors. The focus of this paper, therefore, is the insurance company.

An insurance company is an economic entity set up to manage contributors' funds used specifically to face the risk of uncertainty. Its aim is to offer a kind of relief, on the basis of mutual support, to any of the contributors who get into trouble. The basic principle that binds the contributors is 'the fortune many compensate the unfortunate few'. Working on this basic general rule, insurance companies become the umbrella-institutions under which, contributor-members give their consent to be bound by an honorable common agreement or social contract. However, it has to be emphasized that these elements are those of Islamic takaful and therefore exclusive only to Islamic insurance companies. Not the conventional ones

Takaful Act 1984, Section 2 defines takaful as a scheme based on kinship, solidarity and mutual assistance which provides for mutual financial aid and assistance to the participants in a need whereby the participants mutually agree to contribute for that purpose [1]. The crux of takaful system are the concepts of cooperation, responsibility, guarantee, protection and mutual help between and among the participants [22].

Takaful has a similar role with that of 'aqilah in the pre-Islamic era. During that time, clans swore allegiance to help each member of the clans, through the good and bad times. In the early years of Islam, the kinsmen, as well as 'ahli Diwan', took over the role of the clans. Today, in the absence of 'ahli Diwan' and the clans, the role is taken over by Islamic takaful.

These days, apart from Islamic takaful, there are few other institutions that can serve as alternatives to 'aqilah. They include the government bodies, departments of the governmental agencies, clubs, workers unions, and others. In today's context, based on the concept of 'aqilah as discussed in the preceding pages, since some advantages are exclusive to takaful system, it can, therefore, be accepted as a viable alternative to 'aqilah. The following are some of the advantages: i. Insurance companies are a form of cooperation or a pact between a group of men with the purpose to offer help and provide a guarantee to and for each other. This collaboration is built around a social contract framework that is ever willing to guarantee and help any one of the members who suffer misfortune. Indirectly, this condition fosters the spirits of loyalty and friendship so crucial in developing and nurturing a strong sense of communal responsibility. Gradually, it will lead to a genuine and solid mutual obligation in a society, just as strong as it was, in the times of pre-Islam (Jahiliyyah) and the times of the companions. This is what makes it so special because such will not prevail if the role of 'aqilah is taken over by the government.

ii. Putting the responsibility for Diat to takaful insurance companies means the society has to shoulder the responsibility as well. Hence, lifting a part of the government's responsibility. The government, subsequently, could give much greater attention to other urgent concerns such as the financial matter and infrastructure development for the benefits of the general masses. It could as well allocate more allocations for improving and upgrading existing facilities to prevent road accidents.

iii. As mentioned before, a takaful insurance company serves dual roles: provision of compensation settlement and investment agency for its members. Clearly, the company has two objectives. Firstly, to protect the members against the risk of insecurity and secondly, to work as a secondary means of income. Members stand to gain profits from the investments and any other outstanding profits owed to them or their beneficiary in the event of misfortune. Yet, the most important thing is that a takaful insurance company offers the peace of mind to the contributors - a secured future. Such a sense of security brings with it the feeling of calmness and contentment and hence, putting away greed and obsession with excessive material wealth.

iv. A takaful insurance company usually owns a huge and sufficient fund to shoulder this responsibility. Such a company is national in size and has, under its wing, a large membership. If such a role is entrusted to much smaller agencies such as the associations of teachers, engineers, doctors or even the ministerial as well as the private sectors, there is a real and high risk that some of the agencies will collapse and fail, more often than not due to insufficient funds, especially if one of the agencies has to settle extraordinarily much higher Diat claims than any of the other agencies. The member-victims will be the biggest casualty when justice is poorly delivered.

v. In this context, with the takaful insurance company being the 'aqilah, it consequentially makes the government as the 'Bayt al-Mal'. For members who, 
for inevitable reasons, did not have the opportunity to even make the first contribution to the takaful insurance company and for an accident victim unbeknownst to the perpetrator, as in the hit and run accident, then the responsibility for the Diat compensation lies with the government. 'Bayt al-Mal' and the government, in this context, have equal responsibility and capacity. However, if the government becomes the 'aqilah, it will only need to provide coverage for one million employees currently under its payroll. In contrast, for the private sector's employees, they do not get to enjoy either the security of 'aqilah or 'Bayt al-Mal' because the government cannot be both 'aqilah and 'Bayt al-Mal' all at the same time. In this case, the religious department is then considered to be the 'Bayt al-Mal'. Nevertheless, the capacity and capability of the units of 'Bayt al-Mal' in the religious departments to carry out such a massive responsibility, in line with the requirement of Shariah, remains hugely doubtful.

vi. Now that takaful insurance companies bearing the responsibility of Diat, by no means the system will be completely fool-proof from abuse. The government can apply the method of 'talfiq', that is, accepting all the

vii. scholars' opinions about the liability of the guilty party in Diat settlement. For the School of Hanafi, the guilty party is liable only to $1 / 20$ of Diat value with the School of Maliki specifying 1/3 of the Diat. For the School of Syafi'e, 'aqilah bears in full the Diat value. In this aspect, the government can put into effect certain regulations, especially if it finds the guilty party is greatly negligent, to be liable with Diat settlement as high as $1 / 3$ of the value. In contrast, if the factor of negligence is successfully ruled out, the takaful company, as the 'aqilah, will be fully liable for Diat. The most critical aspect in this matter is the guilty party's degree of negligence. It serves as the ground of the degree of conviction and therefore the value of Diat for the guilty party. Unfortunately, this inadvertently provides a room for abuse in the system. Nonetheless, it also helps to breed the attitude of 'al-zajr' for the public. Accordingly, the system plays two key roles: to compensate the victims and as an effective crime prevention mechanism.

Based on the current situation, it can be safely argued that takaful insurance companies are more than capable of being the 'aqilah so much so that the paper is convinced that they are the only ones fully and completely capable of shouldering the responsibility. As such, the government needs to study a mechanism that could make such a contribution compulsory for every individual. And this is not impossible. Just like the government making income tax compulsory for all citizens, a similar mechanism should work out just fine. There is an exception though - it should be applicable only to the qualified. Only those who have satisfied the requirements would be legally required to make the contributions to Takaful Diat companies.

\section{THE THEORETICAL IMPLEMENTATION OF TAKAFUL DIAT \& RESULTS}

Considering some of the well-deliberated Syariah principles in relation to the proposed implementation of Diat in Malaysia, the paper believes the time is ripe for both the religious scholars and judicial experts to conduct full-fledged research so integral to implement the law on Diat in the country. In order to achieve this goal, both of these groups of experts need to pool their available resources so as to reduce to the minimum the effects of the changes to the existing law, if any. It is important to make sure that, the changes or the introduction of what is seen to be a new foreign law, will be well-accepted and welcomed by the public [4].

As an alternative means to reduce the numbers of road accidents as well as to provide compensation for the innocent victims, the paper seeks to present a theoretical implementation of Diat of which mechanism is almost identical to that of the existing law of Tort. The main reason for this is the almost closeness of the law of Tort, especially in its law of negligence, with those required in Islam. The only difference lies in terms of the quantum of compensation specified by each of the law [19].

Even so, it needs to be stressed that Diat is not compensation per se as it is in the law of Tort. For the law of Tort, there are several mechanisms used to determine the amount of compensation based on the loss of property, self and personality grouped and specified either under general or special damages. The amount of compensation depends on the victims' claims and precedent cases. However, for Diat, the amount of compensation is fixed and determined by Syariah that takes into account injury as the single and sole factor. Diat is the compensation for the loss of life or bodily injury that fits the rates discussed before. This is where the definitions of compensation differ between the conventional law and that of Islam.

In the meantime, Diat is also not to be treated as penalty or punishment as it is commonly and currently understood in the court of law that focuses only on the guilty party. For Diat, it involves both the guilty party and 'aqilah. In addition to that, the penalty paid becomes the property of the state while in Diat, it becomes the property of the victims. As such, Diat can be said to be a unique mechanism, available and provided for only in the criminal law of Islam with purposes to compensate both the victims and the guilty party. The definitions of compensation and the punishment are different from those of the law of Tort because they carry with them the character of Islam as a Syariat [23]. Therefore, the meanings of compensation and punishment as elucidated in this paper, in relation to Diat, are based on the perception of Islam and not the conventional law. 
Having seen the similarities between the law of Tort with that of the Islamic system of Diat, Islamizing the existing law of Tort is much easier as opposed to drafting a new law of Diat. For this purpose, a new model of Diat quantum, 'arsy' and 'hukumah' has to be developed with the local currency serving as the benchmark for the determination of the current value. Additionally, the element of 'aqilah must be redefined to make it contemporary and appropriate with the current needs.

In the context of Diat implementation in Malaysia, when an occurrence of an accident makes a person legally liable to an act of crime, then the plaintiff could file for a compensation claim against the defendant for the loss suffered. The most critical element the plaintiff has to furnish, in his/her claim over unintentional criminal acts, is the presence of negligence on the part of the defendant [14]. Nevertheless, this element will also play a central role in determining the rate of Diat to be borne by the plaintiff in the event the defendant has successfully proven the particular act of crime is of contributory negligence. Contributory negligence is a crime in which the element of negligence is present in both the plaintiff and the defendant. Pursuant to this, the crime of tort has four elements of negligence that need to be proven to be present before a plaintiff can obtain compensation. They are:

1. The duty of care. The plaintiff must prove that the defendant has the duty to care for his/her actions. If the plaintiff fails to prove as such or for which case the defendant does not have the duty to care in a given situation, then the issue of negligence does not arise.

2. Breach of duty. The plaintiff must prove that the defendant is negligent in his/her duty to care according to the determined standards of a given situation. There are two standards as mentioned before. The failure to obey the standards is considered as a form of negligence.

3. Proximate cause. The plaintiff must prove that the defendant is the direct cause of accidents and damage suffered by the plaintiff.

Damage suffered as a result of a breach. The plaintiff must prove that the defendant is able to foresee damages sufferable by the plaintiff as a result of the defendant's negligence. The legal term used is 'predictability of a reasonable person' i.e. predictability of the plaintiff's damages caused by the defendant's negligence. If the damages or losses are unpredictable, the defendant then does not have the duty to care for the plaintiff. In other words, damages suffered by the plaintiff due to the defendant's negligence must not be extraordinarily beyond prediction [8].

Anyhow, if the plaintiff successfully proves the presence of negligence on the part of the defendant, then the latter and his/her 'aqilah will have to pay Diat according to the fixed rate or value. Yet, scholars have not been able to reach a consensus on the rate. For the School of Maliki and Hanbali,
Diat rate stands at a value lesser than 1/3 of Diat. Mazhab of Hanafi, on the other hand, starts the calculation of Diat from $1 / 20$ and below. For the Mazhab of Shafie, 'aqilah is responsible for the payment of Diat in full with the guilty party is exempted from having to incur the burden of Diat.

In the context of its implementation in Malaysia, there is no reason why the opinions of all three Schools cannot be combined via the method of talfiq. Talfiq means amalgamating the Schools' opinions or that of 'mujtahid' to be applied by an individual public (muqallid) in a given law of Syarak [24]. This method is endorsed by scholars as being another source of Islamic law. Plus, it has been commonly practised particularly during the codification process of the law [20]. With the concept of 'talfiq' forming the base, the public is allowed to put into use all the opinions of the renowned scholars in order to establish the minimum and the maximum rates or amount of responsibility a certain guilty party must bear. The fixation of such a rate, however, must take into account the following arguments, among others:

i. The guilty party, innocent and unintentional he/she may be, is still considered to be guilty of being complacent. Hence, the punishment.

ii. In Islamic law, the crime of unintentional murder is punishable with Diat and 'kafarah'. The former refers to the right of a human being while the latter refers to the right of Allah (swt). Refer to Surah al-Nisa', 4:92 'kafarah' is done by freeing a slave of the Islamic faith. Failing of which should be substituted with a straight 60 days of fasting. Since the slavery system has long been abolished, it leaves 60 days of straight fasting as the only means of 'kafarah' available. Although 'kafarah' can also be considered as a form of punishment for the guilty party, by today's standard, it cannot be taken as a punishment that has satisfied the meaning of الردعوالزجر because fasting remains a private type of 'ibadah'. In other words, another form of punishment is warranted so as to achieve the true meaning of الردع والزجر for the guilty party

iii. Accepting only a single opinion of a School will only lead to discrimination. It is entirely possible that the opinion of School of Syafi'e over Diat punishment would unlikely encourage the guilty party to repent since he/she is exempt from paying off Diat. The exemption could hypothetically fail to teach lessons to the guilty party. For the Schools of Maliki and Hanbali, both argue that an accident might occur due to reasons beyond human control, not utter negligence. As such, a Diat punishment (less than 1/3 of Diat) on the guilty party, for an accident beyond one's control, is clear abuse.

The fact is, only by sentencing a guilty party with a punishment that commensurates his/her degree of responsibility for an accident will serve justice in the real sense. For that reason, should an accused is proven beyond doubt, of being negligent in his/her actions, then the burden of Diat must equal the 
proportion of the proven negligence. The School of Maliki and Hanbali set a minimum rate of not more than 1/3 Diat while the Mazhab of Syafi'e sets none i.e. the total sum of Diat must be borne by the 'aqilah. This principle is the fundamental key to determining the quantum of Diat, 'arsy' and 'hukumah' for a particular criminal act.

Furthermore, the rate of Diat is set at 1000 gold dinars or a 22-carat of pure gold ( 0.916 gold) that weighs 4.25 kilogram. This is the rate of one full Diat as practised by the Prophet (saw) during his lifetime and gazetted to be unchangeable by Saidina Umar (ra) ever since. The rate, therefore, remains the same even today. Correspondingly, the rates for 'arsy' and 'hukumah' can be determined according to their fractions against the Diat rate. However, it must be properly understood that the Diat rate is a fixed quantity and cannot be changed. Especially because it falls under the category of 'muqaddarat' (numbers) that comes with it the attribute of 'ta'abbud' (obedience and compliance).

In Malaysia, if 1 gram of gold is valued at RM131.19 (LZS), then the value of a full Diat is RM131.19 x 4250g = RM557,557.50. Accordingly, the values of 'arsy' and 'hukumah' are determined by their fractions against the value of Diat.

\section{CONCLUSION}

Diat is one of the rulings of fiqh elucidated by Allah in Al-Quran and the Prophet's tradition with great detail. In terms of its position in Islam, it equals that of 'solah', fasting, 'zakat' and marriage. The detailed explanation of this ruling can only mean that Allah would not allow any room or space for mortal intervention. Rather, apart from being the principal 'maqasid' in the Syariat of Islam, it is a clear testimony that the issue over Diat, that is, the compensation for the loss of life and bodily injury is an extremely important aspect that human's life can do without. For that reason, there is no excuse for Diat to remain only on the pages of the books of fiqh. It must be applied because its practicality, time and again, has been tested and proven to be capable of living up to the needs and challenges of human's life in all times and places, past, and future. On a final note, it is hoped that the paper has been able to contribute to enriching contemporary Islamic literature.

\section{ACKNOWLEDGMENT}

This project was done under the Universiti Sains Islam Malaysia (USIM) unfunded Grant Schame (PPPI/TB/FSU/11719). Authors would to express their acknowledgment to the researchers from the centre of Research for Fiqh Forensics and Judiciary (CFORSJ) Institute Sain Islam (USIM) for their cooperation.

\section{REFERENCES}

1. Laws of Malaysia, Act 312-Takaful Act. Available: http://www.bnm.gov.my/documents/act/en_takaful _act.pdf.

2. I. A. Idris, Al-Diyah Bayn al-'Uqubah Wa al-Ta'wid Fi Fiqh al-Islami al-Muqarin. Beirut: Dar Wa Maktabah al-Hilal, 1986.

3. A. A. Al-'Aziz, al-Fiqh al-Jina'iy al-Islam, Durub al-Qatl, al-Qisas, al-Diat al-Hudud al-Ta'zir. Amthilah Wa Tatbiqah Nazariyyah. Beirut: Dar al-Salam Li al-Tiba'ah Wa al-Nasyr Wa al-Tawzi' Wa al-Turjumah, 1997.

4. A. 'U. Sa'duddin, Fi Fiqh al-Da'wa Musahamat Fi Ta'sil, 1988.

5. A. A. Badruddin, Al-Binayah Syarh al-Hidayah. Beirut: Dar al-Kutub al-'Ilmiyyah, 2000.

6. M. S. Al-Jundi, Fi Daman al-Darar al-Jasadi al-Natij 'An Fi'l Darr. Dirasah Fi al-Qanun al-Madani al-Urduni Wa Qanun al-Mu'amalat al-Madaniyyah Li Daulah al-Imarat Muwazanah Ma'a Fihayn al-Islami Wa al-Gharbi, 2002.

7. A. M. Bahauddin, Al-'Uddah Syarh al-'Umdah. Dar al-Fikr, n. d.

8. A. V. Venugopal, Introduction to Law in Malaysia. Malaysia, Singapore, Hong Kong: Sweet and Maxwell, 2001A. A. Al-Nadawi, al-Qawa'id al-Fiqhiyyah. Damsyiq: Dar al-Qalam, 1994.

9. A. R. Shamsuddin, Nihayat al-Muhtaj ila Syarh al-Minhaj. Cairo: Matba'ah Mustafa al-Babi al-Halabi Wa Awladuh, 1967.

10. M. A. I. Al-Shāfi'i, al-Umm. Beirut: Dar al-Fikr, 1990.

11. A. S. Muhammad, Al-'Itisam. Cairo: Matba'ah Mustafa Muhammad, n. d.

12. W. Al-Zuhayli, Nazariyyah al-Daman Aw Ahkam al-Mas'uliyyah al-Madaniyyah Wa al-Jina'iyyah Fi al-Fiqh al-Islami. Damsyik: Dar al-Fikr, 1998.

13. W. Al-Zuhayli, "Mas'uliyyah Sa'iq Wasa'il al-Naql al-Jama'iyyah Fi al-Qatl al-Khata' 'An al-Diyah Wa al-Kaffarah," Seminar Majma' al-Fiq al-Islamy ke-14, 2003.

14. M. Anas, Al-Muwatta. Beirut: Dar Ehya' al-Turath al-'Araby, 1997.

15. A. F. Bahnasi, Al-Mawsu'ah al-Jina'iyyah fi al-Fiqh al-Islami. Beirut: Dar al-Nahdah al-'Arabiyyah, 1991.

16. A. F. Bahnasi, Al-Diyah Fi al-Syari'ah al-Islamiyyah. Beirut: Dar al-Syuruq, 1988.

17. A. I. A. M. Ibn Manzur and I. M. A. A. F. J. Al-Din, Lisan 'al-Arab. Beirut: Dar al-Sadr, 1992.

18. S. Z. Ismail, "Penentuan liabiliti doktor dalam kes-kes kecuaian perubatan," Seminar Fiqh Kebangsaan Semasa, 2003.

19. J. Juanda, "Talfiq: Alternatif bagi masalah fiqh semasa," Prosiding Kebangsaan Fiqh Semasa, 2003, pp. 357-370.

20. A. M. Lukman, Diat mengikut realiti kehartaan dan kekeluargaan di Malaysia. Phd thesis, Kuala Lumpur: Universiti Malaya, 2004. 
21. Malaysian Takaful Association, Buku Panduan Asas Takaful. Kuala Lumpur: Islamic Banking and Finance Institute Malaysia, 2010.

22. E. A. Muhammad 'Abduh, Al-Fatawa al-Islamiyyah Min Dar al-Ifta' al-Misriyyah. Cairo: Wizarah al-Awqaf al-Majlis al-Acla Li al-Syu'un al-Islamiyyah, 1993.

23. A. H. E. Muhammady, Sumber Undang-Undang Islam dan Pandangan Orientalis. Selangor: Budaya Ilmu Sdn. Bhd, 1994. 